Thermochimica Acta, 14 (1976) 269-278

C) Elsevier Scientific Publishing Company, Amsterdam - Printed in Bcigium

\title{
THERMAL DECOMPOSITION OF LEAD TITANYL OXALATE TETRAHYDRATE
}

\author{
G. M. H. VAN DE VELDE AND P. J. D. ORANJE
}

Laboratory of Inorganic Chemistry and Materials Science. Department of Chemical Engineering, Tucente Unicersity of Technolog., Enschede (The Netherlands)

(Received 2 September 1975)

\section{ABSTRACT}

The thermal behaviour of $\mathrm{PbTiO}\left(\mathrm{C}_{2} \mathrm{O}_{4}\right)_{2} \cdot 4 \mathrm{H}_{2} \mathrm{O}$ (PTO) has been investigated, employing TG, quantitative DTA, infrared spectroscopy and (high temperature) $X$-ray powder diffraction.

The decomposition involves four main steps. The first is the dehydration of the tetrahydrate $\left(30-180^{\circ} \mathrm{C}\right)$, followed by a small endothermic $\left(270-310^{\circ} \mathrm{C}\right)$ and a large exothermic decomposition of the oxalate. The main (exothermic) oxalate decomposition $\left(310-390^{\circ} \mathrm{C}\right)$ results in a stable oxide-carbonate $\mathrm{PbTiO}_{2.5}\left(\mathrm{CO}_{3}\right)_{0.5}$. In the last step a phase transition, release of $\mathrm{CO}_{2}$ and ordering of the crystalline cubic $\mathrm{PbTiO}_{3}$ lattice can be detected $\left(460-530^{\circ} \mathrm{C}\right)$.

It can be argued that for thermodynamic reasons the presence of lead-oxocarbonates in the oxide-carbonate intermediate is not possible.

No differences could be found in thermal behaviour of two crystaliographically different synthetic forms of PTO, of which one has an orthorhombic lattice.

\section{INTRODUCTION}

As is the case with many fine-grained pure ceramic powders, lead titanate is often synthesized via decomposition of an oxalate complex precursor. The present investigation was undertaken as a part of a larger study of influences of synthesis and thermolysis circumstances on decomposition of i.a. ammonium and lead titanyl oxalate complexes.

When the study of the behaviour of lead titanyl oxalate tetrahydrate.

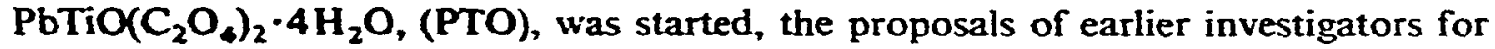
the mechanism of the thermal decomposition of the analogous barium titanyl oxalate (BTO) were highly contradictory ${ }^{1.2}$. It was interesting to see whether the decomposition scheme for the lead compound had a resembiance to any of the proposed schem - or should have a different explanation. There was a possibility that decomposition ce troceed via an oxide-carbonate intermediate, as was found for ammonium titanyl uxalate ${ }^{3}$. During the experiments for this investigation such an intermediate was indeed considered necessary to explain the data. Recently, Gopalakrishnamurthy et al. ${ }^{4}$ published a new repont on BTO decomposition which 
strongly supports the mechanism described here. During decomposition of BTO and PTO there is an intermediate, $\mathrm{BaTiO}_{2.5}\left(\mathrm{CO}_{3}\right)_{0.5}$ or $\mathrm{PbTiO}_{2.5}\left(\mathrm{CO}_{3}\right)_{0.5}$, which in the last step gives off carbon dioxide. There are differences, however, e.g., the presence of two carbonate intermediates in the BTO scheme and the true ionic character of the carbonate ion in $\mathrm{BaTiO}_{2.5}\left(\mathrm{CO}_{3}\right)_{0.5}$.

\section{EXPERIMENTAL}

For the synthesis of pure PTO a method was chosen, viz, precipitation from a $0.1 \mathrm{M}$ ammonium titanyl oxalate solution by dropwise addition of a $0.2 \mathrm{M} \mathrm{Pb}\left(\mathrm{NO}_{3}\right)_{2}$ (Eiaker A.R.) solution. The ammonium titanyl oxalate was synthesized from $\mathrm{TiCl}_{4}$, oxalic acid and ammonia ${ }^{5}$. Both solutions (usually 150 and nearly $75 \mathrm{ml}$, respectively) had a $\mathrm{pH} 0.5\left(\mathrm{HNO}_{3}\right)$ and after adding the reagent the titanyl oxalate was slightly in excess. The precipitate was washed twice with $100 \mathrm{ml}$ of $0.5 \mathrm{M} \mathrm{HNO}_{3}$, twice with $100 \mathrm{ml}$ of water, and was air-dried. The method did not always result in good products, probably due to a thermodynamical preference for lead oxalate and titanium hydroxide precipitation ${ }^{6}$.

The product was analysed by the method of EDTA/ $\mathrm{H}_{2} \mathrm{O}_{2}$ addition (for $\mathrm{Pi} \div \mathrm{Ti}$ ) or EDTA/lactic acid addition (for $\mathrm{Pb}$ ) and back-titration of the excess EDTA with a standard lead solution ${ }^{7}$. Oxalate was determined in $\mathrm{H}_{2} \mathrm{SO}_{4}$ solution of the sample (containing $\mathrm{PbSO}_{4}$ ) by permanganate titration.

$\mathrm{X}$-ray powder patterns were taken with a Philips diffraction spectrometer PW-1310, with a Nonius Guinier-De Wolff camera and with a Nonius Guinier-Lenné high-temperature carrera, all with $\mathrm{CuK} x_{1}$ radiation, $\lambda=1.5405 \AA$.

Thermal analyses were carried out with a DuPont $950 / 900$ thermal analyzer, using TG and a quantitative DTA cell, with 10-mg samples, and with a Stanton TR-01 thermo-recording balance. The latter was applied for the use of greater quantities of material (more than $100 \mathrm{mg}$ ), for analyses of intermediate products at different decomposition stages. The heating rate was $10^{\circ} \mathrm{C} \mathrm{min}^{-1}$ and the thermal analyses were usually carried out in stationary air at ambient pressure. Infrared spectra were taken with a Perkin-Elmer 257 spectrometer (using $\mathrm{KBr}$ pellets).

RESULTS

When the stoichiometry was correct, a typical result of chemical analysis was: $\mathrm{Pb}:$ 39.32, Ti: 9.38, $\mathrm{C}_{2} \mathrm{O}_{4}: 33.60$ weight $\%$; calculated values for $\mathrm{PbTiO}\left(\mathrm{C}_{2} \mathrm{O}_{4}\right)_{2}$ $4 \mathrm{H}_{2} \mathrm{O}: \mathrm{Pb}: 39.91, \mathrm{Ti}: 9.23, \mathrm{C}_{2} \mathrm{O}_{4}: 33.91, \mathrm{H}_{3} \mathrm{O}: 13.88 \%$.

Even with ideal stoichiometry, the product could be either X-ray amorphous or have one of two possible structures, of which the powder patterns are given in Table 1. The first one has been found, by computer analysis of the powder diffraction data $^{8}$, to be orthorhombic with cell parameters $a=11.555 \AA, b=16.274 \AA$ and $c=6.361 \AA$. For the density was found $2.80 \mathrm{~g} \mathrm{~cm}^{-3}$, which corresponds with four units per cell (theoretical density: $2.883 \mathrm{~g} \mathrm{~cm}^{-3}$ ). The four units probably consist of 
one tetramer, because the titanyl oxalate anion in the ammonium compound is a cyclic tetramer ${ }^{5}$, or possibly they consist of two dimeric units.

TABLE 1

X-RAY POWDER DIFFRACTION PATTERNS OF TWO FORMS OF $\mathrm{PbTiO}\left(\mathrm{C}_{2} \mathrm{O}_{4}\right)_{2} \cdot 4 \mathrm{H}_{2} \mathrm{O}, \mathrm{Cu} K x_{2}$ RADLATION, $\lambda=1.5405 \AA$, GUINIER-DE WOLFF CAMERA

\begin{tabular}{|c|c|c|c|c|c|c|c|c|c|}
\hline \multicolumn{5}{|c|}{ A. Ortharhombic } & & \multicolumn{4}{|c|}{ B. Unit cell unknourn } \\
\hline \multicolumn{6}{|c|}{$\begin{array}{l}a=11.555 A, b=16.274 A, c=6.361 A \\
Z=4, d_{x}=2.883 \mathrm{~g} \mathrm{~cm}^{-3}\end{array}$} & \multirow[b]{2}{*}{$d(A)$} & \multirow[b]{2}{*}{$I / I_{1}$} & \multirow[b]{2}{*}{$d(A)$} & \multirow[b]{2}{*}{$I / I_{1}$} \\
\hline$d(A)$ & $I / I_{1}$ & $h k I$ & $d(A)$ & $I_{i} I_{2}$ & $h k I$ & & & & \\
\hline 8.14 & 70 & 020 & 2.669 & 3 & 132 & 9.59 & 60 & 3.52 & 5 \\
\hline 6.65 & 4 & 120 & 2.636 & 40 & 222 & 7.81 & 20 & 3.46 & 20 \\
\hline 5.78 & 80 & 200 & 2.590 & $<I$ & 251 & 7.63 & 10 & 3.36 & 7 \\
\hline 5.57 & 35 & 101 & 2.560 & 80 & 341 & 7.37 & 1 & 3.32 & 10 \\
\hline 5.27 & $<1$ & 111 & 2.506 & 10 & 042 & 6.59 & 100 & 3.29 & 35 \\
\hline 5.01 & 50 & 021 & 2.495 & 10 & 061 & 6.24 & 10 & 3.26 & 1 \\
\hline 4.71 & 75 & 220 & 2.478 & 15 & 232 & 6.07 & 10 & 3.24 & 5 \\
\hline 4.60 & 75 & 121 & 2.439 & 25 & 161 & 5.94 & 5 & 3.20 & $<1$ \\
\hline 4.14 & $<1$ & 211 & 2.355 & 30 & 440 & 5.65 & 75 & 3.17 & 25 \\
\hline 4.07 & 7 & 040 & 2.315 & 25 & 351 & 5.48 & 60 & 3.11 & 20 \\
\hline 3.89 & 3 & 131 & 2.299 & 15 & 242 & 4.91 & 20 & 3.04 & 3 \\
\hline 3.84 & 30 & 140 & 2.291 & 10 & 261 & 4.83 & 1 & 2.981 & 15 \\
\hline 3.79 & 15 & 221 & 2.232 & 5 & 152 & 4.79 & 20 & 2.948 & 3 \\
\hline 3.43 & 15 & 041 & 2.218 & 50 & 360 & 4.75 & 20 & 2.916 & 15 \\
\hline 3.33 & 45 & 240 & 2.209 & 15 & 441 & 4.62 & 5 & 2.878 & 10 \\
\hline 3.29 & 70 & 141 & 2.172 & 35 & 501 & 4.53 & 5 & 2.820 & 10 \\
\hline 3.18 & 20 & 002 & 2.138 & 15 & 402 & 4.45 & 15 & 2.750 & 3 \\
\hline 3.12 & 2 & 012 & 2.120 & 15 & 003,412 & 4.37 & 10 & 2.726 & 2 \\
\hline 3.05 & 70 & 321 & 2.099 & 100 & 521,342 & 4.24 & 55 & 2.676 & 10 \\
\hline 2.962 & 25 & 022 & 2.086 & $<1$ & 103 & 4.19 & 45 & 2.641 & 10 \\
\hline 2.948 & 10 & 241 & 2.068 & 40 & 113,422 & 4.13 & 3 & 2.629 & 15 \\
\hline 2.889 & 90 & 400 & 2.046 & 3 & 451 & 4.05 & 10 & 2.587 & 10 \\
\hline 2.811 & 25 & 151 & 2.032 & 15 & 162 & 3.95 & 5 & 2.547 & 5 \\
\hline 2.797 & 25 & 340 & 2.020 & 2 & 123 & 3.90 & 15 & 2.529 & 10 \\
\hline 2.746 & 20 & 212 & 2.009 & 35 & 540 & 3.76 & 2 & 2.499 & 5 \\
\hline 2722 & 65 & 420 & 2.003 & 2 & 180 & 3.75 & 1 & 2.475 & 5 \\
\hline 2.712 & 20 & 060 & 1.989 & $<1$ & 432 & 3.58 & 40 & 2.393 & 10 \\
\hline
\end{tabular}

The other compound, which was the one formed in most cases, was used for this thermal investigation. Cell parameters could not yet be found, because of the more diffuse powder diffraction lines. It has been observed, however, that TG and DTA curves for both samples were identical. A third compound, described by, e.g., Strizhkov et al. ${ }^{9}$ as $\mathrm{PbTiO}\left(\mathrm{C}_{2} \mathrm{O}_{4}\right)_{2} \cdot \mathrm{H}_{2} \mathrm{C}_{2} \mathrm{O}_{4} \cdot 4 \mathrm{H}_{2} \mathrm{O}$, synthesized by using an extra equivalent of oxalic acid in the ammonium titanyl oxalate solution, could only once be isolated in a yield which was too small to substantiate this composition. However, the powder diffraction pattern was the same as that described by those authors. 
Figure 1 gives the TG and DTA curves for PTO in air. Dehydration occurs in one step between 30 and $180^{\circ} \mathrm{C}$ (I). The water-free product is $X$-ray amorphous. As indicated in Table 2 the sample contained a slight excess of adsorbed water.

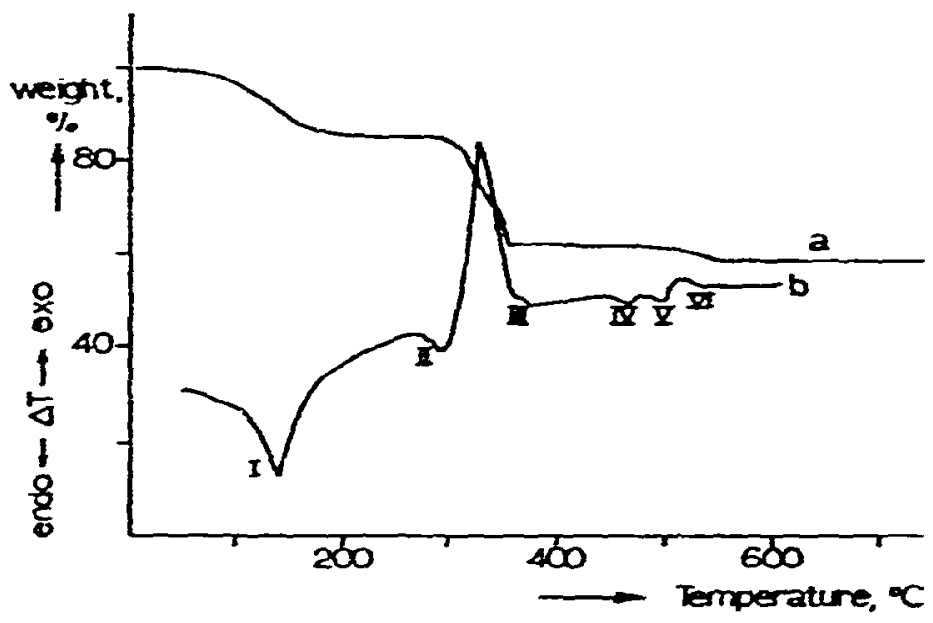

Fig. 1. TG and DTA curves of decomposition of $\mathrm{PbTiO}\left(\mathrm{C}_{2} \mathrm{O}_{3}\right)_{2}-4 \mathrm{H}_{2} \mathrm{O}$ in static air, atmospheric pressure. (a) TG, sample weight $10 \mathrm{mg}$ (DuPont) or $130 \mathrm{mg}$ (Stanton); (b) DTA. sample weight $10 \mathrm{mg}$ (DuPont quartitative DTA accessory).

\section{TABLE 2}

DECOMPOSITION OF PTO IN STATIC AIR ATMOSPHERE, HEATING RATE $10^{\circ} \mathrm{C} \mathrm{min}^{-1}$

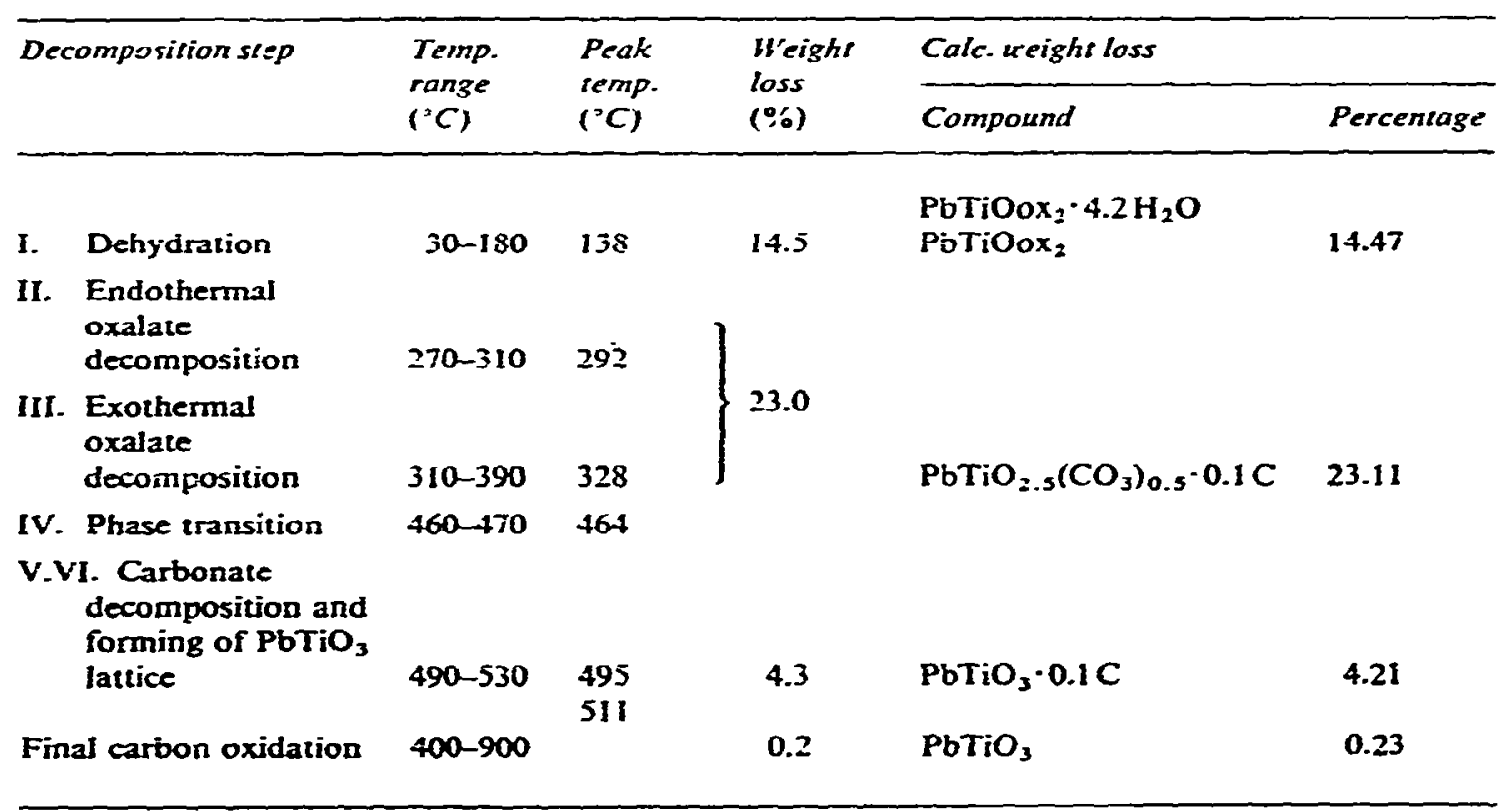


The oxalate decomposition involves two steps (Fig. 1: II, III), one endothermic peak immediately followed by a large exothermic peak. This latter is absent when the compound is decomposed in nitrogen. Therefore, it is most probably caused by an overwhelming exothermic effect of $\mathrm{CO}$ oxidation in this temperature region (3i0$340^{\circ} \mathrm{C}$ ), which is possibly catalyzed by small quantities of reactive $\mathrm{PbTiO}_{3}$ or $\mathrm{PbTiO}_{3}$ precursor ${ }^{10}$. As a small percentage of carbon is always found in the residue at the end the small exothermic effect of the Boudouard disproportionation of $\mathrm{CO}$ is masked by the other effects. The weight loss after the endothermic part was approximately $24 \%$ which is in agreement with the formula $\mathrm{PbTiO}_{1.5}\left(\mathrm{C}_{2} \mathrm{O}_{4}\right)\left(\mathrm{CO}_{3}\right)_{0.5}$ (75.95 weight \% of original quantity) and a loss of $1 \mathrm{CO}$ and $\frac{1}{2} \mathrm{CO}_{2}$ per mole. However, DTA and TG are not simultaneous so the initial temperatures of the reactions may be different and there is no definite proof that such an intermediate really exists. After the exothermic part the weight loss is $37.5 \%$ which is in agreement with $\mathrm{PbTiO}_{2.5}\left(\mathrm{CO}_{3}\right)_{0.5}$, an oxide-carbonate. The $\mathrm{CO}_{2}$ content of this compound was confirmed by chemical analysis. The composition turned out to be independent of the apparatus and sample weight, in contrast to what was found for $\mathrm{TiO}_{2-x}\left(\mathrm{CO}_{3}\right)_{x}$ during decomposition of the ammonium compound ${ }^{3}$.

Infrared spectra of PTO and of samples taken at different decomposition stages are shown in Fig. 2. This clearly shows that during decomposition of the oxalate typical oxalate vibration frequencies are gradually replaced by carbonate bands which are typical for an oxide-carbonate or an oxide which strongly adsorbs carbon dioxide (see, e.g.. Turcotte et al. ${ }^{1}$, who describe $\mathrm{ia}_{2} \mathrm{O}_{2}\left(\mathrm{CO}_{3}\right)$ ). The small differences with i.r.-spectra of lead-oxo-carbonates ${ }^{12}$, however, do not exclude the possibility of a $\mathrm{TiO}_{2}-\left(\mathrm{PbO} \cdot \mathrm{PbCO}_{3}\right)_{0.5}$ compound.

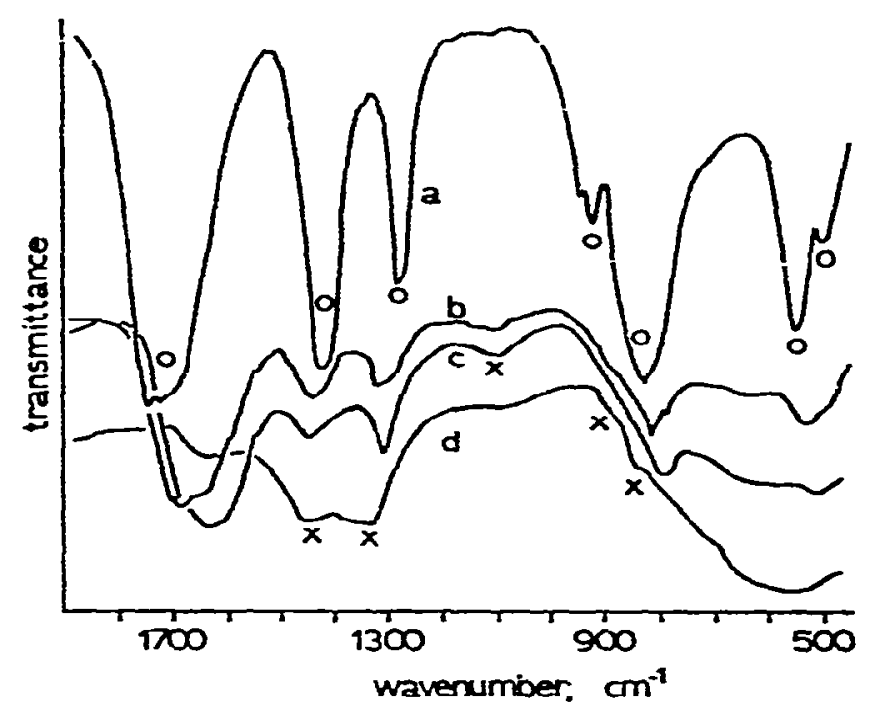

Fig. 2. Infrared spectra of $\mathrm{PbTiO}\left(\mathrm{C}_{2} \mathrm{O}_{3}\right)_{2}-4 \mathrm{H}_{2} \mathrm{O}$ and decomposition products. $\mathrm{O}=$ oxalate, $x=$ carbonate. $(a)=$ PTO; $(b)=$ fraction of starting weight $0.77 ;(c)=0.69:(d)=0.615$. 
From an analysis of DTA curves of $\mathrm{PbCO}_{3}, \mathrm{TiO}_{2}-\mathrm{PbCO}_{3}$ powder mixtures and a $\mathrm{TiO}_{2} \cdot x \mathrm{H}_{2} \mathrm{O}-\mathrm{PbCO}_{3}$ coprecipitate it was found that $\mathrm{PbCO}_{3}$ always decomposes into the oxide tefore it reacts with $\mathrm{TiO}_{2}$. This is in agreement with results of Bergstein ${ }^{13}$, who reported $\mathrm{PbTiO}_{3}$ is only iormed above $500^{\circ} \mathrm{C}$ after $\mathrm{PbCO}_{3}$ decomposition when $\mathrm{PbCO}_{3}$ and anatase are the starting materiais. For the above reasons it is unlikely that lead-oxo-carbonate is present in the intermediate.

The following step (Fig. 1: IV, V, VI) is the decomposition of the carbonate and formation of the $\mathrm{PbTIO}_{3}$ (cubic phase) lattice. Actually IV (at $460^{\circ} \mathrm{C}$ ) is a reversible phase-transition of $\mathrm{X}$-ray amorphous $\mathrm{PbTiO}_{3}$ (still containing carbonate and a small amount of carbon) to the cubic perovskite lattice. The reversible character only occurs once during cooling, later on the formed $\mathrm{PbTiO}_{3}$ has its normal tetragonal/ cubic perovskite transition at $490^{\circ} \mathrm{C}$. The formation of cubic phase at lower temperatures is even more remarkable with high-temperature $\mathrm{X}$-ray powder diffraction. At very slow heating rates the diffraction lines of the cubic phase appear after the $\mathrm{X}$-ray amorphous state between 410 and $460^{\circ} \mathrm{C}$. After cooling to $300^{\circ} \mathrm{C}$ cubic and tetragonal phase lines appear together during reheating until transition to cubic phase at about $460^{\circ} \mathrm{C}$. This temperature changes to $490^{\circ} \mathrm{C}$ after another cooling and heating cycle. These results correspond with the transition which usually occurs at $490^{\circ} \mathrm{C}$ (Curie temperature) but which is lower during decomposition of PTO due to the highly defective lattice of the product. (See also for dependence of Curie temperature on substitution of dopes, e.g., Shirasaki ${ }^{14}$.)

The endothermic effect followed by an exothermic effect (V, VI) is probably caused by the (endothermic) carbonate decomposition, partly overlapped by exothermic lattice ordering.

The product then still contains about 0.4 weight $\%$ carbon which can be removed by prolonged heating at a higher temperature, preferable below $850^{\circ} \mathrm{C}$ to prevent $\mathrm{PbO}$ vaporization ${ }^{15}$.

Microscopic investigation has shown that the original PTO particles keep their macroscopic appearance (brick-like aggregates of about $5 \mu \mathrm{m}$ ), during decomposition, which means that neither dehydration nor degassing cause fragmentation. Synthesis of PTO with small particles will therefore result in $\mathrm{PbTiO}_{3}$ with small particles.

\section{DISCUSSION}

As mentioned for BTO by Gopalakrishnamurthy et al. ${ }^{4}$ the first endothermic peak during BTO decomposition in the temperature range of $200-250^{\circ} \mathrm{C}$ is ascribed to the loss of half a mole of carbon monoxide per mole of BTO. For PTO it is more reasonable to think of a process which involves more than only balf a mole of $\mathrm{CO}$. Some reasons are: the temperature region for PTO is higher, the endothermic effect is relatively much more pronounced and contains a slight shoulder in the peak and the total weight loss seems more than $17 \%$ for the formation of $\mathrm{PbTiO}\left(\mathrm{C}_{2} \mathrm{O}_{4}\right)_{1.5}\left(\mathrm{CO}_{3}\right)_{0.5}$ In the case of PTO it is possible that one mole of $\mathrm{CO}$ and half a mole of $\mathrm{CO}_{2}$ evolve (total weight loss $23.5 \%$ ), leading to $\mathrm{PbTiO}_{1.5}\left(\mathrm{C}_{2} \mathrm{O}_{4}\right)\left(\mathrm{CO}_{3}\right)_{0.5}$, with the i.r. spectrum 
b in Fig. 2, but as stated before this is not necessarily a definite intermediate compound.

From this hypothetical state it would take a further loss of one mole of $\mathrm{CO}$ and one mole of $\mathrm{CO}_{2}$ to get the stable oxide-carbonate $\mathrm{PbTiO}_{2.5}\left(\mathrm{CO}_{3}\right)_{0.5}$. This formula is preferred to $\mathrm{PbTiO}_{3} \cdot 0.5 \mathrm{CO}_{2}$ because of the stable character of this product, which is not influenced by sample weight (10-130 mg), heating rate or type of apparatus.

As stated before, the formation of a separate lead-oxo-carbonate is not very probable. To support this a thermodynamic calculation of the free enthalpies of formation of $\mathrm{PbTiO}_{3}$ from the oxides and from $\mathrm{PbCC}_{3} / \mathrm{TiO}_{2}$ or $0.5\left(\mathrm{PbO} \cdot \mathrm{PbCO}_{2}\right)$ ) $\mathrm{TiO}_{2}$ was performed.

TABLE 3

FREE REACTION ENTHALPIES $\triangle G\left(\mathrm{kcal} \mathrm{mol}^{-1}\right)$ FOR SOME OXIDE/CARBONATE EQUILIBRIA

\begin{tabular}{|c|c|c|c|c|c|c|c|}
\hline \multirow[t]{2}{*}{ Reaction } & \multicolumn{7}{|c|}{ Temperature $(K)$} \\
\hline & 300 & 400 & 500 & 600 & 700 & 800 & 900 \\
\hline $\begin{array}{l}\text { (a) } \mathrm{PbO} \text { (yellow) } \div \mathrm{TiO}_{2} \text { (anatase) } \leftrightarrows \\
\mathrm{PbTiO}_{3}\end{array}$ & -6.15 & -7.10 & $-8.0 \overline{7}$ & -9.06 & -10.30 & -11.60 & -12.97 \\
\hline (D) $\mathrm{PbCO}_{3} \div \mathrm{TiO}_{2} \rightleftarrows \mathrm{PbTiO}_{3}+\mathrm{CO}_{2}$ & 3.33 & -1.46 & -6.36 & -11.35 & -16.46 & -21.68 & -27.02 \\
\hline $\begin{array}{l}\text { (c) } \underset{1}{1}\left(\mathrm{PbO}-\mathrm{PbCO}_{3}\right) \div \mathrm{TiO}_{2} \rightleftarrows \\
\mathrm{PbTiO}_{3}+1 \mathrm{CO}_{2}\end{array}$ & 0.20 & -2.67 & -5.60 & -8.60 & -11.67 & -14.83 & -18.10 \\
\hline (d) $\mathrm{PbCO}_{3} \rightleftarrows \mathrm{PbO}+\mathrm{CO}_{2}$ & 9.48 & 5.64 & 1.71 & -2.29 & -6.35 & -10.40 & -14.62 \\
\hline
\end{tabular}

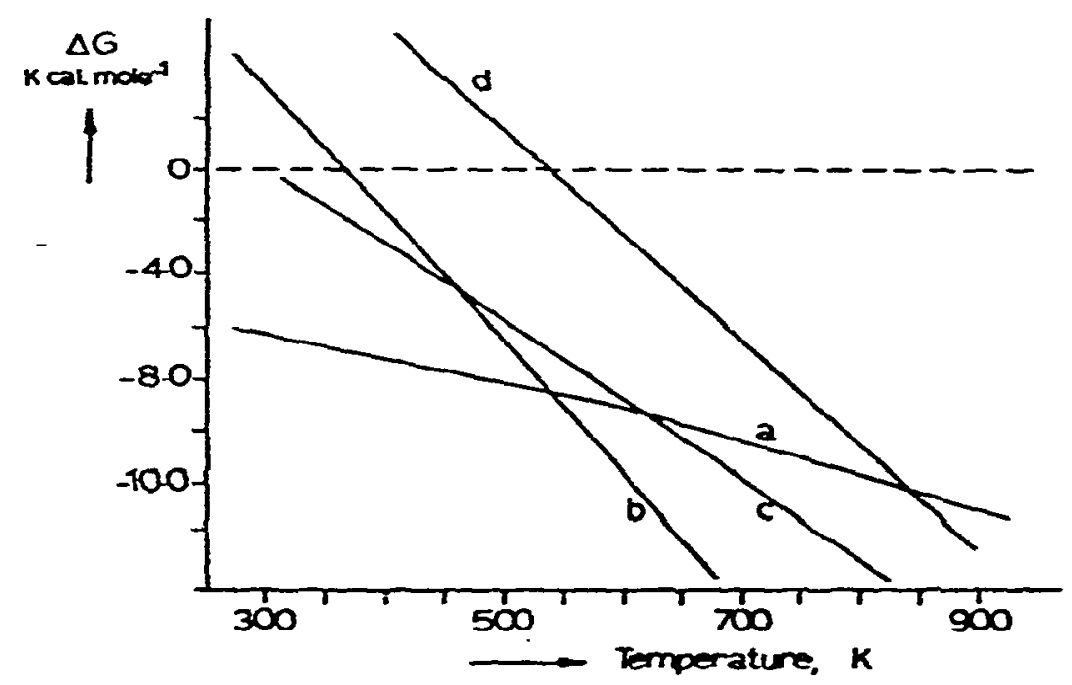

Fig. 3. Free reaction exthalpies $\Delta G$ as a function of temperature for oxide/carbonate equilibria (cf. data Table 3). 
Table 3 and Fig. 3 have been calculated using the values of $\Delta H_{\mathrm{PbTiO}_{3}}^{\mathrm{o}}=$ $-273.7 \mathrm{kcal} \mathrm{mol}^{-1}$ and $\Delta G_{\mathrm{PbTiO}_{3}}^{\mathrm{O}}=-256.1 \mathrm{kcal} \mathrm{mol}^{-1}$, taken from Zharkova ${ }^{16}$ and using the usual enthalpy-temperature relationship formulas. The same calculation has been performed with the values $\Delta H_{\mathrm{PbTiO}}^{0}=-277.9$ and $\Delta G_{\mathrm{PbTiO}}^{\mathrm{o}}=-257.3 \mathrm{kcal}$ $\mathrm{mol}^{-1}$, taken from Schwitzgebel ${ }^{17}$, but as the results were not significantly difierent they have not been included. Other $\Delta H, \Delta G, c_{P}$ or $p$ data were from ${ }^{18.19}\left(\mathrm{TiO}_{2}\right)^{20}$ $(\mathrm{PbO})$ and $^{21}\left(\mathrm{PbCO}_{3}, \mathrm{PbO} \cdot \mathrm{PbCO}_{3}\right)$.

Figure 3 clearly shows (cross points $a-b$ and $a-c$ ) that the lowest temperature at which $\mathrm{PbTiO}_{3}$ is formed just as easily (thermodynamically) from $\mathrm{PbCO}_{3} / \mathrm{TiO}_{2}$ as from $\mathrm{PbO} / \mathrm{TiO}_{2}$ lies at about $540 \mathrm{~K}\left(270^{\circ} \mathrm{C}\right)$ and for $\mathrm{PbO} \cdot \mathrm{PbCO}_{3}$ at about $615 \mathrm{~K}$ $\left(345^{\circ} \mathrm{C}\right)$. Above these temperatures the carbonates will decompose to $\mathrm{PbO}$. However, the rate of formatica of $\mathrm{PbTiO}_{3}$ from the oxides only becomes significant at still higher temperatures.

This means that there is no real possibility for a compound $\mathrm{TiO}_{2}(\mathrm{PbO}$ $\left.\mathrm{PbCO}_{3}\right)_{0.5}$ to give $\mathrm{PbTiO}_{3}$ in the temperature range of $460-530^{\circ} \mathrm{C}$, in contrast to $\mathrm{PbTiO}_{2.5}\left(\mathrm{CO}_{3}\right)_{0.5}$.

The results are in agreement with the following decomposition scheme:

$$
\begin{aligned}
& \mathrm{PbTiO}\left(\mathrm{C}_{2} \mathrm{O}_{4}\right)_{2} \cdot 4 \mathrm{H}_{2} \mathrm{O} \stackrel{30-180^{\circ} \mathrm{C}}{\longrightarrow} \operatorname{PbTiO}\left(\mathrm{C}_{2} \mathrm{O}_{4}\right)_{2} \\
& \mathrm{PbTiO}\left(\mathrm{C}_{2} \mathrm{O}_{4}\right)_{2} \stackrel{270-390^{\circ} \mathrm{C}}{\longrightarrow} \mathrm{PbTiO}_{2.5}\left(\mathrm{CO}_{3}\right)_{0.5} \\
& \text { and } \mathrm{CO}+\frac{1}{2} \mathrm{O}_{2} \longrightarrow \mathrm{CO}_{2} \\
& \text { and } 2, \mathrm{CO} \\
& \mathrm{PbTiO}_{2.5}\left(\mathrm{CO}_{3}\right)_{0.5} \stackrel{460-530^{\circ} \mathrm{C}}{\longrightarrow} \mathrm{PbTiO}_{3}
\end{aligned}
$$

and slowly

$$
\begin{aligned}
& \mathrm{yr} \div \mathrm{i}: \mathrm{O}_{2} \\
& \stackrel{400-900^{\circ} \mathrm{C}}{\longrightarrow} y \mathrm{CO}_{2} \\
& \text { with } y=0.1
\end{aligned}
$$

In the decomposition of BTO another intermediate is found by Gopalakrishnamurthy et al. ${ }^{4}$ prior to the final oxide-carbonate, viz., $\mathrm{BaTiO}_{2.5}\left(\mathrm{CO}_{3}\right)_{0.5}$. $\downarrow \mathrm{CO}_{2}$, which loses $\frac{1}{2} \mathrm{CO}_{2}$ between 450 and $600^{\circ} \mathrm{C}$, without any pronounced heat effect. Such an intermediate is not detected in the decomposition of PTO.

The presence of a $2350 \mathrm{~cm}^{-1}$ vibration band in the i.r. spectra of the intermediate in the BTO decomposition and preceding oxalate-carbonate stages and the absence thereof in the last oxide-carbonate is used as an argument for $\mathrm{CO}_{2}$ adsorbed or retained by that intermcdiate. This is a free carbon dioxide band but often occurs in the spectra of many carbonates and carbonate complexes as well, and can thus not be used as a diagnostic band for adsorbed carbon dioxide. 
In the case of PTO the band (outside the frequency range shown in Fig. 2) also appears in all oxalate-carbonate stages and remains in the oxide-carbonate, in contrast to what is observed for the analogous $\mathrm{Ba}$ compound. The infrared spectrum of the latter compound is also different, mainly in the nearly symmetrical $1450 \mathrm{~cm}^{-1}$ band and in the sharpness of other bands. analogous to the spectrum of an "ionic" carbonate such as $\mathrm{PbCO}_{3}$.

The exact nature of the oxide-carbonate in the PTO scheme is not known; for reasons mentioned before adsorbed or entrapped $\mathrm{CO}_{2}$ is not considered probabie. We feel that a $\mathrm{PbTiO}_{3}$ lattice in which some oxygen ions are replaced by carbonate ions is a more probable structure.

\section{Note addea in proof}

The nature of the intermediate $\mathrm{PbTiO}_{2.5}\left(\mathrm{CO}_{3}\right)_{0.5}$ was recently confirmed by a combined EGA-TG experiment on a sample of PTO which had been heated in air at $320^{\circ} \mathrm{C}$ during $48 \mathrm{~h}$. The weight loss during the carbonate decomposition step in a gasflow of helium corresponded with 0.497 mole of $\mathrm{CO}_{2}$ which was evolved exclusively. The experiment was kindly performed by Mr. A. Broersma, Dept. of Inorganic Chemistry, State University of Utrecht, in a combination of a Cahn RH electrobalance, a Leybold-Heraeus Topatron-B gas analysis instrument and a DuPont 900 thermal analyzer for temperature programming.

\section{ACKNOWLEDGEMENTS}

The authors express their appreciation to Miss M. M. A. Perik for part of the chemical and thermal analyses and Dr. P. J. Gellings for his helpful discussions.

\section{REFERENCES}

1 B. Y. Strizhkov, A. V. Lapitskii and L. G. Vlasov, Zh. Prikl. Khim., 33 (1960) 2009.

2 P. K. Gallagher and J. Thomson, Jr., J. Am. Ceram. Soc., 48 (1965) 644.

3 G. M. H. van de Velde and P. J. D. Oranje, Therm. Anal. Proc. Int. Conf., 4th 1974, Budapest, Vol. 1, p. 851.

4 H.S. Gopalakrishnamurthy, M. Subba Rao and T. R. Narayanan Kutty, J. Inorg. Nucl. Chem., 37 (1975) 391.

5 G. M. H. van de Velde, S. Harkema and P. J. Gellings, Inorg. Chim. Acra, 11 (1974) 243.

6 G. M. H. van de Velde and P. J. Gellings: to be published.

7 M. M. A. Perik and P. J. D. Oranje, Anal. Chim. Acta, 73 (1974) 402.

8 J. W. Visser, J. Appl. Crystallogr., 2 (1969) 89.

9 B. V. Strizhkov, A. V. Lapitskii, Yu. P. Simanov and L. G. Vlasov, Zh. Neorz. Khim., 7 (1962) 2181.

10 D. W. Johnson, Jr. and P. K. Gallagher, Thermochim. Acta, 7 (1973) 303.

11 R. P. Turcotte, J. O. Sawyer and L- Eyring, Inorg. Chem., 8 (1969) 238.

12 S. D. Ross and J. Goldsmith, Spectrochim. Acta, 20 (1964) 781.

13 A. Bergstein, Chem. Listy, 50 (1956) 3.

14 S. I. Shirasaki and K. Takahashi, J. Am. Ceram. Soc., 56 (1973) 430.

15 K. H. Härdu and H. Rau, Solid Stare Commun., 7 (1969) 41.

16 L. A. Zharkova, Zh. Fiz. Khim., 36 (1962) 1819. 
17 K. Schwitzgebel, P. S. Lowell, F. B. Parsons and K. J. Sladek, J. Chem. Eng. Data, 16 (1971) 418.

18 O. Kubaschewski and E. L. Evans, Metollurgical Thermockemistry, Pergamon, London, 3rd ed., 1958.

19 M. Kh. Karapet'yants and M. L. Karapt'yants, Thermodynamic Contants of Inorganic and Organic Compourds, Ann Arbor-Humphrey Science Publishers, Ann Arbor, 1970.

20 C. B. Alcock and T. N. Belford, Trans. Faraday Soc., 60 (1964) 822.

21 M. Centnerswer, G. Falk and A. Awerbusch, Z. Phys. Chem., 115 (1925) 29. 